\title{
Effect of Bilge Keels Position On Roll Motion Performance Of Traditional Wooden Boat
}

\author{
Muhammad Akbar Asis ${ }^{1}$, Daeng Paroka ${ }^{2}$, Syamsul Asri $^{3}$, Muhammad Anjas Syam ${ }^{4}$ \\ (Received: 09 September 2020 / Revised: 20 September 2020 / Accepted: 22 September 2020)
}

\begin{abstract}
GT and 500GT, including traditional wooden boats. The accidents were dominated by capsizing due to bad weather. Therefore the safety of traditional wooden boats needs to be improved. This paper discusses the position of bilge keels and their impact on the roll motion performance of an Indonesian traditional wooden boat. The roll damping is determined by a roll decay test with three different positions of bilge keels, namely 15 degrees, 30 degrees, and 45 degrees. The roll amplitude is determined in the frequency domain by solving the uncoupled nonlinear roll motion equation with an effective wave slope coefficient calculated using the simplified Froude-Krylov assumption of roll exciting moment. The bilge keels position with the angle of 15 degrees reduced the roll amplitude of $18 \%$ while the position with an angle of 30 degrees decreases the roll amplitude by $7 \%$ of roll amplitude without bilge keels. The bilge keels position with an angle of 45 degrees reduced the roll amplitude by $2 \%$ of those without bilge keels. The natural roll period was not significantly affected by the bilge keels position. The bilge keels position with an angle of 15 degrees is the most effective position to reduce the roll amplitude.
\end{abstract}

Keywords $\longrightarrow$ wooden boat, bilge keel, damping, stability, and roll motion.

\section{INTRODUCTION}

$\mathrm{T}$ he traditional wooden boats are mostly used as cargo ships for inter-island transportation with a short distance, inland ships, or operated in the restricted areas, especially in the region with minimum port facilities. They play an important role in sea transportation in Indonesia to develop connectivity of undeveloped regions, outermost area as well as an isolated area to the main route of the national sea transportation system [1]. In the marine tourism sector, the traditional wooden boats are currently very popular as cruise ships because of the historical and aesthetic values so that the safety of wooden boats recently needs to be improved as well as the convenience of operating at sea. The ship accident, such as sinking, is still dominant compared to the other types of accidents, such as fire, collision, and ground. Based on data from the National Transportation Safety Committee of Indonesia (KNKT) in the year of 2013, the number of accidents due to sunk was 67 casualties [2]. This number is larger than the other types of accidents. The main cause is bad weather and technical factors. To improve safety and comfort, the aspect that needs to be studied hydrodynamic characteristics, which are very related to the stability and motion of ships at sea.

The literature shows that the hydrodynamic performance of a traditional ship mainly correspond to

Muhammad Akbar Asis, Department of Naval Architecture, University of Hasanuddin, Indonesia. E-mail: muhammadakabarasis@gmail.com

Daeng Paroka, Department of Ocean Engineering, University of Hasanuddin, Indonesia. E-mail: dparoka@eng.unhas.ac.id Syamsul Asri, Department of Naval Architecture, University of Hasanuddin, Indonesia. E-mail: sa tanri kapal83@yahoo.com

Muhammad Anjas Syam, Department of Naval Architecture, University of Hasanuddin, Indonesia. E-mail: anjassyam77@gmail.com the bilge keels effect has not been investigated [3]. There are many traditional boat building companies in Indonesia, and most of them are still using conventional methods to design traditional boats, which are based on traditional practices and experiences. Therefore it is necessary to conduct hydrodynamics and seakeeping analysis for such wooden boats so that their safety, efficiency, and performance can be enhanced and optimized [3].

Roll motion has a significant effect on the safety and operation performance of ships in seaways. Furthermore, the ships have a risk of capsizing due to a large roll angle under the extreme sea and severe weather conditions. Here, the damping moment is a key factor in avoiding a large roll angle [4]. A ship encounters extreme beam seas or oblique waves with a frequency close to the natural rolling frequency leading to large roll amplitude with high nonlinearity [5]. Several types of research correspond to roll damping moments have extensively been conducted, including the estimation methods. In some cases, the roll amplitude is reduced by increasing the damping moment with stabilization techniques such as using an anti-rolling tank or using bilge keels [6]. However, the study was conducted for merchant ships with geometric characteristics very different from the geometry of Indonesian traditional wooden boats. The stabilization devices have also never been applied to the traditional wooden boats. The effectiveness of antirolling devices such as the bilge keels depends on the geometry of bilge keels and it's position on the ship hull [7]. The bilge keels can reduce the roll amplitude by about $30 \%$ [8]. The damping factor corresponds to the bilge keels in the weather criterion ranges of 0.70 to 1.00 depending on the ratio of bilge keels area and the product between the length of waterline and ship breadth. For ships with geometry characteristics different from those used to develop the weather criterion of International Maritime Organization (IMO), a different value of damping factor correspond to bilge keels was obtained 
[9]. This means that the available damping factor in the weather criterion is valid only for ships with geometry characteristics the same as those used to develop the weather criterion. A semi-empirical method to estimate roll damping has been provided by Ikeda [10]. However, this method can only be used for ships with breadth-todraught ratio smaller than 2.67 , for containership (single screw) with breath-to-draught ranges from 2.5 to 2.67, series 60 with block coefficient of 0.6 valid for breadth to draught ratio 2.3, and for ellipsoid shape hull for a breadth-to-draught ratio of 2.0.

The other methods to estimate the roll damping are using numerical simulation such as CFD. [5], [7] and model experiment [11]. These methods can be used for unconventional ships such as the Indonesian traditional wooden boats because the calculation procedures are based on the hull form without simplification. From a practical point of view, these two methods seem to be more appropriate to be used for Indonesian traditional wooden boats if the experimental approach cannot be conducted.

Several studies have been conducted to determine the effective position of the bilge keel for roll stability enhancement of traditional wooden boats such as strip theory, CFD. Methods and experimental by using ship scale models with various shapes, positions, and sizes of the bilge keel as studied [3], [11]. Here, the dimension of bilge keels was determined based on the ratio of the length of the bilge keel to the length of the waterline. It was found that the length of bilge keels to effectively reduce the roll angle was 0.4 of the length waterline. This phenomenon shows that the length of the bilge keels is getting longer [12]. Apart from the size of the bilge keels, it is also necessary to determine the location of the bilge keel because the bilge keels also provide additional resistance if the bilge keels location does not match the flow around the ship hull. The position of the bilge keel mounted on the radius bilge has a significant effect, while the position of the bilge keel mounted on the bottom or near the keel area is not effective in reducing motion [7]. The radius bilge of the Indonesian traditional wooden boats with a large rise of the floor is different from that for modern ships. Therefore the effective position of bilge keels could be different from that for modern ships.

This paper discusses the effect of bilge keels position on roll damping of Indonesian traditional wooden boats.

This is important because the bilge keels were not yet introduced to the Indonesian traditional wooden. The effectiveness of the bilge keels is evaluated based on the reduction of roll amplitude in beam seas. The results can be used as a reference for the builder of traditional wooden boats to install the bilge keels in order to increase the safety level as well as to improve performance on the traditional wooden boats, mainly when operating in beam seas.

\section{METHOD}

The subject ship used in this paper was a traditional wooden boat built in the traditional shipbuilding in Bulukumba, South Sulawesi. The principles dimension and the body plan of the ship with the position of bilge keels are shown in Tabel 1 and Figure 1, respectively. The variation of bilge keels position is determined based on the angle measured from the centerline with origin in the water surface. There are three different positions of bilge keels analyzed consist of the angle of 15 degrees, 30 degrees, and 45 degrees, respectively. The bilge keels dimension is determined based on the bilge keels used by a built traditional wooden boat.

The damping coefficients are determined by the model experiment of roll decay tests with the procedure recommended by the International Towing Tank Conference (ITTC) [13]. The initial roll angle was set to be 25.0 degrees with recorded data until the roll amplitude the same as 0.5 degrees. Here, the coefficients correspond to the linear, and the quadratic damping coefficients are statistically calculated by using a polynomial regression equation, as shown in the equation

TABLE 1.

PRINCIPLE DIMENSION

\begin{tabular}{cll}
\hline No & \multicolumn{1}{c}{ Parameter } & \multicolumn{1}{c}{ Value } \\
\hline 1 & Length (L) & 22,8 meter \\
2 & Breadth (B) & 4,8 meter \\
3 & Height $(\mathrm{H})$ & 1,6 meter \\
4 & Draught $(\mathrm{d})$ & 1,12 meter \\
5 & Vertical center of gravity $(\mathrm{KG})$ & 1,58 meter \\
6 & Block coefficient & 0,362 \\
\hline
\end{tabular}

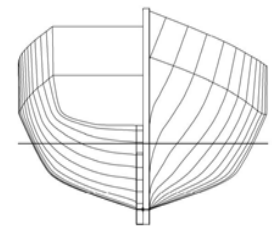

(a)

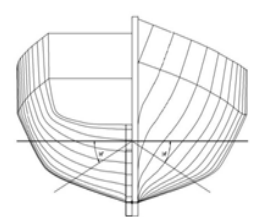

(c)

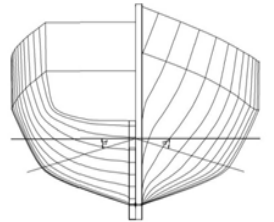

(b)

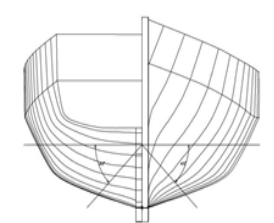

(d)

Figure. 1. Body plan and bilge keels position: (a) wihtout bilge keels; (b) 15 degress; (c) 30 degrees (d) 45 degress 
(1) [14].

$$
\Delta \phi=a \phi_{m}+b \phi_{m}^{2}
$$

Where $a$ and $b$ are the coefficients, correspond to the linear dan the quadratic damping coefficients, respectively. $\Delta \phi$ is the decrement of two consecutive roll amplitudes (degree) in the roll decay test and $\phi_{m}$ indicates the average of two consecutive roll amplitudes (degree). The linear and the nonlinear damping coefficients are calculated by using the equation as follows:

$\alpha=\frac{a \omega_{0}}{\pi}$
$\beta=\frac{3 b}{4}$

Here, $\omega_{0}$ indicates the natural roll frequency, which is obtained from the roll decay test.

In order to show the effect of bilge keels position on the roll motion of a ship in beam seas, the roll motion is calculated by using an uncoupled nonlinear roll motion equation as follow:

$\left(I_{x x}+A_{44}\right) \ddot{\phi}+B_{44} \dot{\phi}+B_{N} \dot{\phi}|\dot{\phi}|+\Delta G Z(\phi)=M(t)$

where, $I_{x x}$ and $A_{44}$ are the mass moment of inertia and the added moment of inertia, respectively. is the roll acceleration, $B_{44}$ and $B_{N}$ indicate the linear and the quadratic damping moments, respectively. $\phi$ is the roll angle with the roll acceleration, and the angular velocity is designated by $\ddot{\phi}$ and $\dot{\phi}$, respectively. $\Delta$ is the displacement and $G Z(\phi)$ is the righting arm. $M(t)$ is wave exciting moment. Here, the righting arm of the ship was modeled with a fifth-order polynomial equation, as shown in the following equation:

$$
G Z(\phi)=a_{1} \phi+a_{2} \phi^{3}+a_{3} \phi^{5}
$$

The effective wave slope coefficient is calculated at the natural roll frequency based on the simplified FoudeKrylov assumption of wave exciting moment as recommended by IMO [15]. The effective wave slope coefficient is assumed to be independent of wave frequency. The nonlinear roll motion equation is analytically solved in the frequency domain with two different wave slopes of 0.04 and 0.06 , respectively. These wave slopes were based on the wave data recorded in the Indonesian area [16].

The obtained roll amplitude at the resonance frequency is then compared with that for a ship without bilge keel in order to obtain the effect of bilge keel position on roll motion in beam seas.

\section{RESULT AND DISCUSSION}

\section{Roll period}

The natural roll period obtained by roll decay tests for a ship without and with bilge keels are shown in Figure 2. This figure shows that the natural roll period does not significantly change due to bilge keels for all bilge keels position. The roll natural period of the ship without bilge keels was 4.14 seconds, and that for the ship with bilge keels position with 15 degrees of the slope was 4.18 seconds. For merchant ships such as an Indonesian ro-ro ferry, the natural roll period increases due to bilge keels [9]. The different results could occur due to dimension of bilge keels. The added inertia induced by bilge keels depends on dimension of bilge keels. The bilge keels also induce friction and lift forces to decrease roll angular velocity. Therefore the natural roll period of ship with bilge keel larger than that without bilge keels.

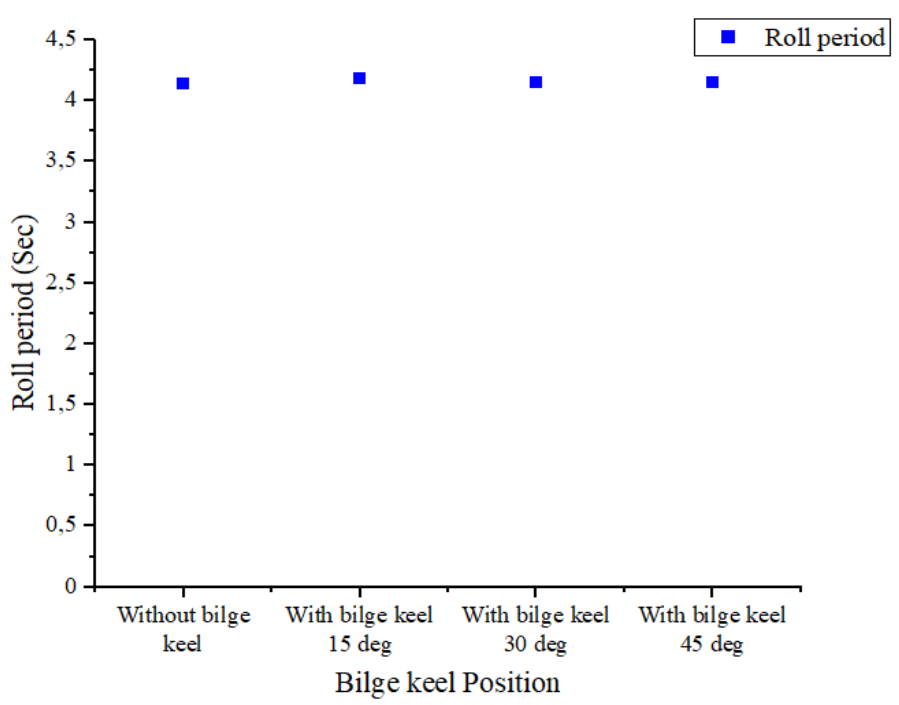

Figure. 2. Natural period obtained by roll decay tests 
Figure 3 shows the time history of the roll decay test for the ship without bilge keels and the ship with three different bilge keels positions. This figure shows that the roll amplitudes of a ship with bilge keels position with a slope of 15 degrees are smaller than those for the position of the other of the bilge keels. The roll amplitudes for the bilge keels position with a slope of 30 degrees and 45 degrees are larger than those for the ship coefficients tends to decrease as the slope of bilge keels position increases. The percentage of change in the linear damping coefficient without bilge keel and that with bilge keel at a slope of 15 degrees was $6.31 \%, 0.61 \%$ for the slope of 30 degrees, and for the slope of 45 degrees was $0.45 \%$. While the nonlinear damping coefficient increase approximately $0.43 \%$ for the bilge keels position with a slope of 15 degrees. For the slope of 30

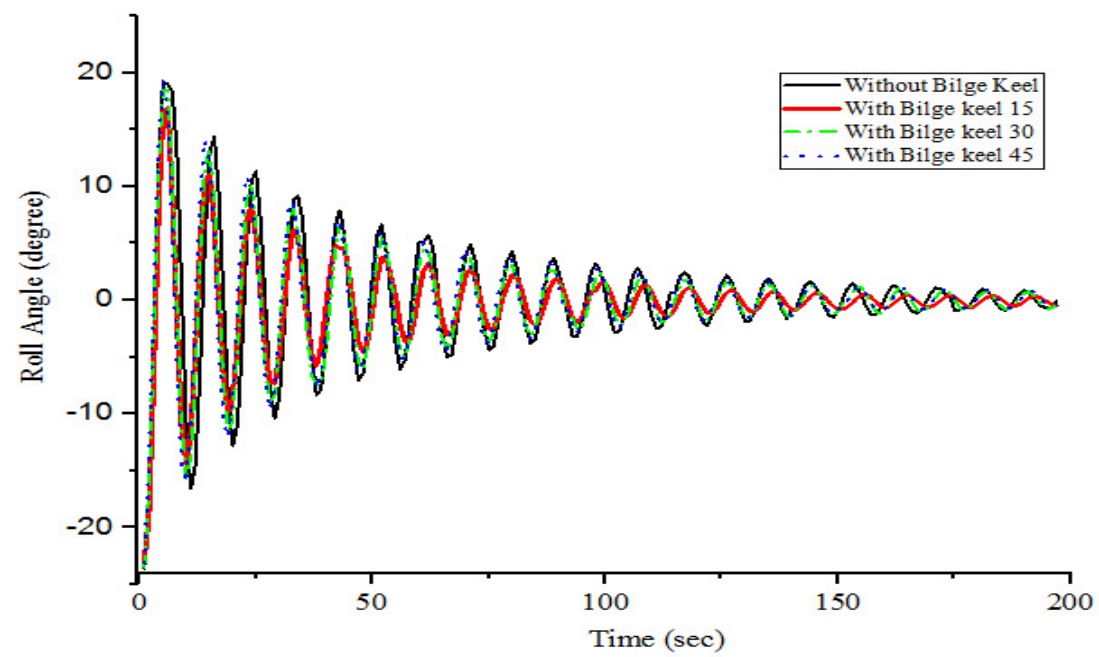

Figure. 3. Roll decay with variation angle bilge keel

without bilge keels. The roll amplitude of the roll decay test tends to decrease as the slope of the bilge keels position increases. Alteration of the natural roll period occurs due to the increase of added inertia induced by the bilge keels depends on its position. A similar result of the alteration of the natural roll period has been found by Paroka et al. [9].

\section{Damping coefficient on the results of roll decay}

The second-order polynomial regression based on results of roll decay tests for a ship without bilge keels and with three different positions of bilge keels are shown in Figure 4 with the linear and quadratic coefficients correspond to the polynomial regression degrees of bilge keels position, the quadratic damping coefficient increases by about $0.16 \%$. The increasing quadratic damping coefficient due to bilge keels position with a slope of 45 degrees was $0.05 \%$. It can be concluded that the bilge keels position with a slope of 15 degrees has the largest effect on damping coefficients.

Previous research was conducted by Irkal et al. [17] shows that the linear and the quadratic damping coefficients increase with increasing the width of bilge keels. The most effective bilge keels position to increase the damping coefficients was in the transition from the bottom to the side hulls (radius bilge) of the ship. Similar results regarding the position of bilge keels to effectively increase the damping coefficient have been found by $\mathrm{Gu}$, et al. [7]. For merchant ships, the bilge keels may reduce

TABLE 3.

DAMPING COEFFICIENT RESULT FROM ROLL DECAY TES

\begin{tabular}{ccc}
\hline Damping Coeficient & b & a \\
\hline Without Bilge & 0,01352 & 0,08565 \\
With Bilge keel 15 Degree & 0,01779 & 0,14878 \\
With Bilge keel 30 Degree & 0,01512 & 0,09177 \\
With Bilge keel 45 Degree & 0,01403 & 0,09016 \\
\hline
\end{tabular}

coefficients shown in Table 3. The results show that the change in the position of the bilge keel induces different linear and quadratic damping coefficients. The linear and the quadratic damping coefficients significantly increase due to bilge keels for bilge keels position with a slope of 15 degrees. The effect of bilge keels to damping the roll amplitude by approximately 30\% [8]. The other factor that should be considered regarding the position of bilge keels is the distance from the center of gravity which has also significant effect on the damping moment induced by the bilge keels [18]. 


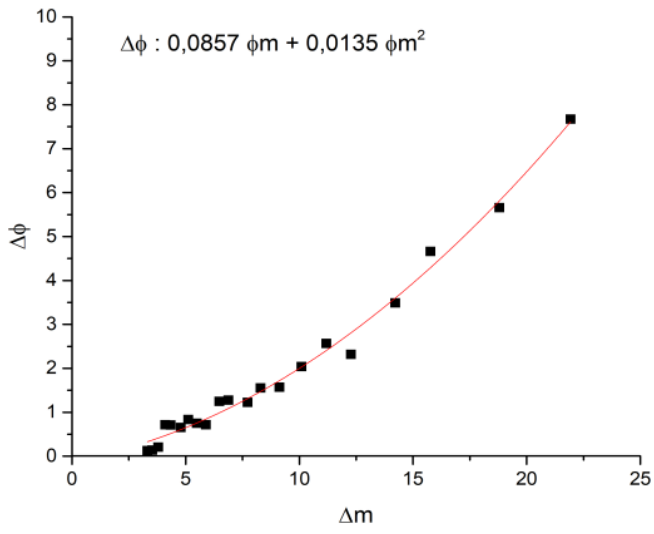

(a)

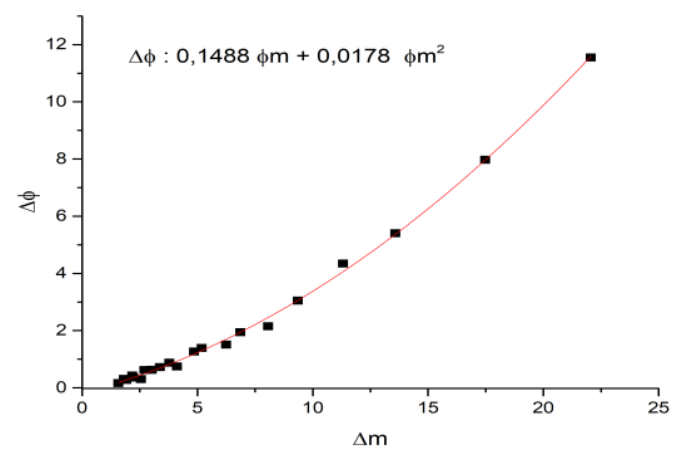

(b)

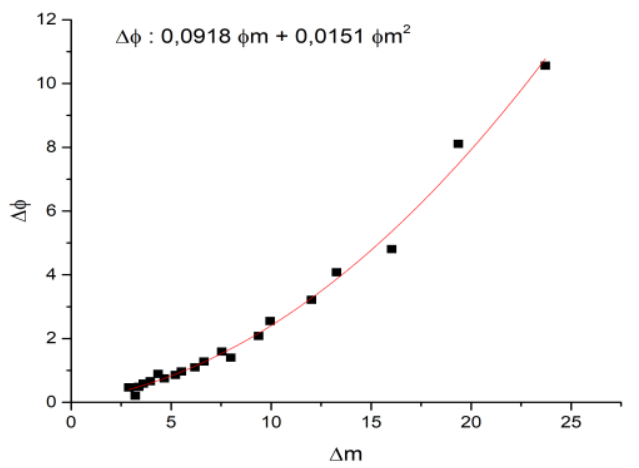

(c)

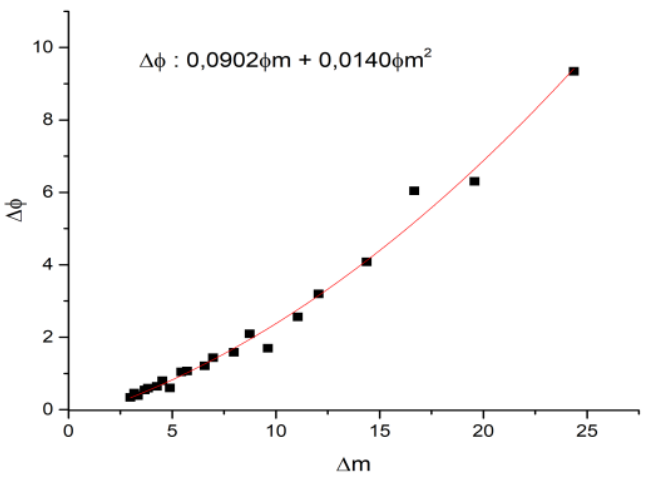

(d)

Figure. 4.Extinction coefficient of roll decay test of ship without and with different position of bilge keels: (a) without bilge keels; (b) 15 degrees; (c) 30 degrees; (d) 45 degrees 


\section{Ship roll motion response}

Using the obtained damping coefficients, the roll response of the ship in beam seas is calculated by using the equation (5). The roll response in the frequency domain is shown in Figure 5a for wave steepness of 0.04 and Figure $5 b$ for wave steepness of 0.06 , respectively. Here, the effective wave slope coefficient was calculated based on the simplified Froude-Krylov assumption of an exciting wave moment. amplitude of roll decreases to be 30.72 degrees or decreasing about $18 \%$, when the ship uses bilge keels located with a slope angle of 15 degrees. Reduction of roll amplitude about $7 \%$ was found in the bilge keels position determined with a slope angle of 30 degrees. Here, the maximum roll angle in beam seas is 34.85 degrees. The roll amplitude for bilge keels position with a slope angle of 45 degrees is 36.5 degrees correspond to a reduction of approximately 3\%. Fesman, et al. [8] found that the bilge keels may reduce the roll amplitude

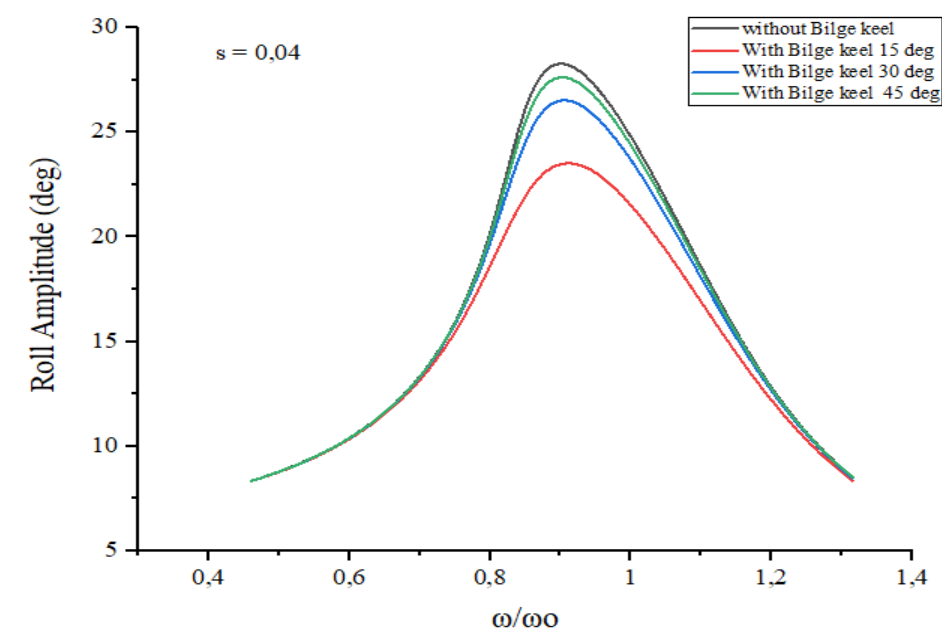

(a)

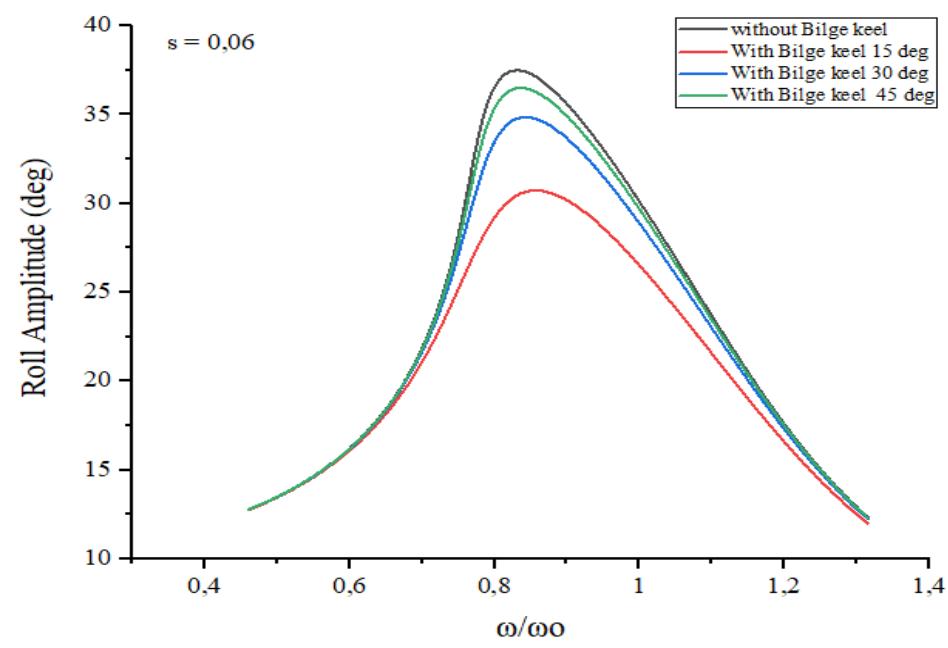

(b)

Figure. 5. Roll amplitude: (a) wave steepness of 0,04; (b) wave steepness of 0,06

The maximum roll amplitude of ship without bilge keels is 28.2 degrees in wave steepness of 0.04 . The roll amplitude decreases to be 23.51 degrees, corresponding to a reduction of approximately $17 \%$ for bilge keels position with a slope angle of 15 degrees. The maximum roll amplitude for the bilge keels position with a slope angle of 30 degrees is 26.5 degrees, decreasing about $6 \%$ due to bilge keels. A smaller reduction of roll amplitude of approximately $2 \%$ corresponds to the roll amplitude of 27.6 degrees was obtained for the bilge keels position with a slope of 45 degrees. A similar trend of bilge keels effect on roll motion in beam seas has been found for the wave steepness of 0.06 . The roll amplitude of the ship without bilge keels is 37.5 degrees. The maximum by more than $30 \%$. A smaller reduction of roll amplitude obtained in the present study could be due to a different dimension of the bilge keels. Different geometric characteristics may also induce the different effects of bilge keels on the roll motion of ships. Katayama et al. [18] found that the distance of the bilge keels to the center of gravity also has a significant effect on the damping coefficient induced by the bilge keels. In order to obtain the parameters significantly affect the damping moment due to bilge keels, a numerical investigation fro different bilge keels position is necessary for future works.

Figure 6 shows the percentage of alteration of maximum roll amplitude of the ship in beam seas due to 


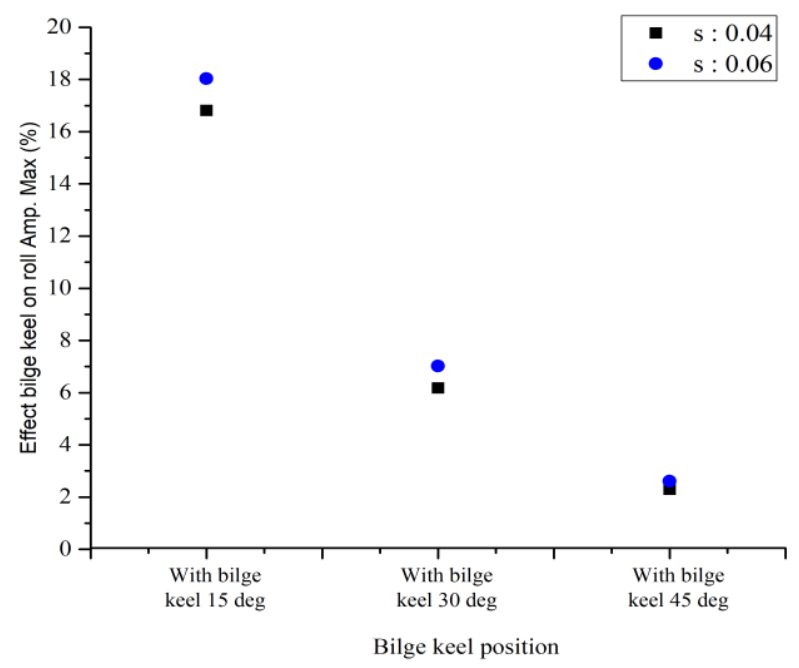

Figure. 6.Percentage change of roll amplitude max (\%)

different position of bilge keels for wave steepness of 0.04 and 0.06 , respectively. This percentage of alteration of roll amplitude for different positions of bilge keels could be different for different geometric characteristics. Therefore, the relationship between the geometry of bilge keels and the maximum roll amplitude is important to investigate in the future works.

\section{CONCLUSION}

The roll motion of a traditional wooden boat without and with bilge keel with different position has been analyzed. The bilge keel position with a slope of 15 degrees induced the most significant effect on increasing the linear and the nonlinear damping coefficients compared to the bilge keels position with a slope of 30 degrees and 45 degrees. The natural roll period increase due to an increase in the slope of the bilge keel position, but the difference was not significant. The roll amplitude was reduced by approximately $18 \%$ due to bilge keels with a slope position of 15 degrees. The reduction of roll amplitude due to bilge keels for the bilge keels position with a slope of 30 degrees and 45 degrees was $8 \%$ and $3 \%$, respectively. The obtained reduction of roll amplitude was smaller than that obtained by the other study. Those differences could occur because of the bilge keels' geometry. Therefore, the optimum bilge keels geometry for Indonesian traditional wooden boats should be investigated in the future.

\section{ACKNOWLEDGMENTS}

The content of this paper is a part of research supported by the Directorate General of Higher Education (DIKTI) and Hasanuddin University with grand number 1516/UN4.22/PT.01.03/ 2020. The authors express their sincere gratitude to those institutions for their support.

\section{REFERENCES}

[1] D. Paroka, A.H. Muhammad, S. Rahman, and M.A. Asis, "Operational limitation of Indonesia traditional wooden boat in the framework of the second generation intact stability criteria," presented at the Sustainable Island Development Initiatives Conference, Surabaya, Indonesia, 2019.

[2] B. Prihartono" Development of tol laut in the Middle-term National Development Plan 2015-2020 and its implementation on 2015," National Development Planning Agency of Indonesia, 2015 (in Indonesian).

[3] W. Liu, Y.K. Demirel, E.B. Djatmiko, S. Nugroho, T. Tezdogan, R.E. Kurt, H. Supomo, I. Baihaqi, Z. Yuan and A. Incecik, "Bilge keel design for the traditional fishing boats of Indonesia's East Java"., Int. J. of Naval Arch. and Ocean Eng., vol. 11(1), pp. $380-$ 395, Jan. 2019.

[4] C.C. Bassler and A.M. Reed, "An analysis of the bilge keel roll damping component model," presented at the 10th Intl. Conf. On Stability of Ships and Ocean Vehicles, St. Petersburg, Rusia, 2009.

[5] M.A.R. Irkal, S. Nallayarasu and SK. Bhatracharyya, "Numerical prediction of roll damping of ships with and without bilge keel," Ocean Engineering, vol. 179(2019) pp. 226-245, 2019.

[6] G.G. Cox and A.R. Lloyd, "Hydrodynamic design basis for navy ship roll motion stabilization," SNAME Transaction, vol. 85, pp. $51-93,1977$.

[7] Y. Gu, S. Day and E. Boulougouris, "A study on the effect of bilge keels on roll damping coefficient," presented at the $12^{\text {th }}$ Int. Conf. on the Stability of Ships and Ocean Vehicles, Glasgow, UK, 2015.

[8] E. Fesman, D. Bayraktar and M. Taylan, "Influence of damping on the roll motion of ships," presnted at the 2 nd Int. Conf. on Marine Research and Transportation, Naples, Italy, 2007.

[9] D. Paroka, S. Asri, Rosmani and Hamzah, "Alternative assessment of weather criterion for ships with large breadth and draught ratio by model experiment: a case study on an Indonesian ro-ro ferry", Int. J. of Maritime Engineering vol. 162(1), pp. 55 64, 2020.

[10] Y. Ikeda, K. Komatsu, Y. Himeno and N. Tanaka," On roll damping force of ship -effect of hull surface pressure created by bilge keel," Dept. of Naval Architecture, University of Osaka Prefecture, 1979.

[11] H. Hendratmoko, Hasanudin and I.K.A.P. Utama, "Experimental study on effect of bilge keels on roll motion," J. Teknik vol.1(1), pp. G.94 - G.97, 2012 (in Indonesian).

[12] PKDNY. Putra, BH. Iskandar and Y. Novita, "Using length of bilge keel to length of waterline ratio to reduce ship rolling motion," Eng. Tech. \& App. Science Research, vol. 8(2), pp. $2731-2734,2018$. 
[13]ITTC, "Recommended procedures: numerical estimation of roll damping," presented at the 26th ITTC Specialist Committee on Stability in Waves, Rio de Jeneiro, Brazil, 2011.

[14]IMO, "MSC.1/Circ.1200 - Interim guidelines for alternative assessment of the weather criterion," London, UK, 2011.

[15] IMO, "SDC 1/INF.6 - Development of second generation intact stability criteria: vulnerability assessment for dead-ship stability failure mode," 2013.

[16] P. Berrisford, D.P. Dee, P. Poli, R. Brugge, K. Fielding, M. Fuentes, P.W. Kallberg, S. Kobayashi, S. Uppala and A. Simmos,
"The ERA Interim Archive Version 2.0. Report Series 1," http://ecmwf.int/en/elibrary/8174, 2011.

[17] M.A.R. Irkal, S. Nallayarasu and SK. Bhattacharyya, "CFD approach to roll damping of ship with bilge keel with experimental validation," App. Ocean Research, vol. 55, pp. 1 $17,2016$.

[18] T. Katayama, M. Matsuoka and K. Ikushima, "Characteristics of bilge keel roll damping component for shallow draft," presented at the 13th Int. Conf. on the Stability of Ships and Ocean Vehicles Kobe, Japan, 2018. 